Jurnal Agro 7(1), 2020

\title{
SELEKSI DAN INDEKS SENSITIVITAS CEKAMAN KEKERINGAN GALUR-GALUR PADI SAWAH TADAH HUJAN
}

\section{SELECTION AND DROUGHT SENSITIVITY INDEX OF RAINFED RICE LINES}

\author{
Wage Ratna Rohaeni* dan Untung Susanto \\ Balai Besar Penelitian Tanaman Padi, JI. 9 Sukamandi, Kec. Ciasem, Subang, Indonesia \\ Korespondensi : $\underline{\text { wagebbpadi@gmail.com }}$
}

Diterima : 26 November 2018/ Disetujui : 2 Juli 2020

\begin{abstract}
ABSTRAK
Cekaman kekeringan hampir terjadi setiap tahun pada sawah tadah hujan. Salah satu teknologi untuk mengatasinya adalah dengan penanaman padi toleran kekeringan. Pe rakitan varietas toleran kekeringan terus dilakukan dengan mengevaluasi galur-galuryang ditujukan untuk stress kekeringan. Penelitian ini bertujuan untuk menyeleksi, mengevaluasi pe nu runan hasil, dan mengetahui indeks sensitivitas cekaman kekeringan pada galur-galur tadah hujan hasil seleksi generasi lanjut. Percobaan seleksi cekaman kekeringan di lakukan pada MaretNovember 2016 dengan materi genetik sebanyak 135 galur dan Cek Mekongga yang ditanam pada kondisi stress kekeringan (61-72 centibar/Kpa) dan evaluasi galur - galur terseleksi dilakukan pada Februari - Juli 2017 dengan menggunakan rancangan acak kelompok 3 ulangan. Hasil kegiatan seleksi memperoleh sebanyak 19 galur terbaik memiliki toleransi terhadap stres kekeringan untuk dilanjutkan pada kegiatan evaluasi lebih lanjut di kondisi sawah tadah hujan kondisi optimum. Hasil penelitian evaluasi 19 galur menunjukkan sebanyak 4 galur toleran yaitu BP17586-2-0-JK-3-IND-2-SKI-10-PWK-1-SKI-2 (ISK 0.49), BP18354-1-2-JK-3IND-1-SKI-3-PWK-1-SKI-1 (ISK 0.49), BP18360-2-3-JK-1-IND-1-SKI-7-PWK-2SKI-1 (ISK 0.16), dan BP18406C-JK-1-IND-0-SKI-3-PWK-2-SKI-1 (ISK 0.1). Galur BP18354-1-2-JK-3-IND-1-SKI-3-PWK-1SKI-1 $\left(Y=4,77\right.$ ton ha $\left.^{-1}\right)$ adalah galur terbaik yang memiliki potensi hasil tinggi lebih baik dari cek Inpari 38 Tadah Hujan dan memiliki toleransi terhadap cekaman kekeringan. Galur ini potensial untuk diuji lebih lanjut dan dikembangkan di sawah tadah hujan.
\end{abstract}

Kata kunci: galur, indeks sensitivitas cekaman, kekeringan, tadah hujan

\section{ABSTRACT}

Drought stress almost occurs every year in rainfed rice fields. One of the technologies to overcome is by planting drought tolerant varieties rice. Therefore, the assembly of drought tolerant varieties is carried out continuously by evaluating lines intended for drought stress. This study aimed to select, evaluate the decline in yield, and determine the drought tole rance index of rainfed lines resulting from advanced generation selection. Study-1 of drought stress selection experiment was carried out in WS 12016 (March - November) with 135 geneticlines and Mekongga as susceptible checks and Inpari 38 as resistant check planted in drought stress conditions (61-72 centibar / Kpa), and study-2 was an evaluation of selected strains carried out in WS 12017 (February - July) with 19 selected lines and 3 checks (Mekongga and Ciherang as susceptible check and Inpari 38 as resistant checks) by using a randomized block design with 3

Cyte this as: Rohaeni, W, R. \& Susanto, U. (2020). Seleksi dan indeks sensitivitas cekaman kekeringan galur-galur padi sawah tadah hujan. Jurnal Agro, 7(1), 71-81. https://doi.org/10.15575/3654 
replications. The results of the selection activities (Study-1) obtained as many as 19 of the best lines which had tolerance to drought stress and these lines were continued in further evaluation activities in rainfed lowland with optimum conditions (Study-2). The results showed that 4 of 19 lines were tolerant namely BP17586-2-0-JK-3-IND-2-SKI-10-PWK-1-SKI-2 (DSI drought stress sensitivity index $=0.49$ ), BP18354-1 -2-JK-3-IND-1-SKI-3-PWK-1-SKI-1 (DSI 0.49), BP18360-2-3-JK-1-IND-1-SKI-7-PWK-2SKI-1 (DSI 0.16), and BP18406c-JK-1-IND-0-SKI-3-PWK-2SKI-1(DSI 0.1). The BP18354-1-2-JK-3-IND-1-SKI-3-PWK-1-SKI-1 $\left(Y=4.77\right.$ tons ha $\left.^{-1}\right)$ line was the best strain that had the potential for high yield better than the Inpari 38 Rainfed Check and had tolerance to stress. This strain has the potential to be further tested and developed in rain-fed rice fields.

Key words : drought, lines, rainfed, sensitivity index

\section{PENDAHULUAN}

Padi (Oryza sativa L.) merupakan salah satu sumber pangan utama di Indonesia. Tidak hanya di Indonesiaa, padi juga telah menjadi sumber pangan utama di dunia terutama di Asia (Rohman et al., 2014). Luas lahan padi dunia diperkirakan mencapai 153,76 juta ha dan $27 \%$ dari produksi padi berasal dari padi gogo dan sawah tadah hujan (Maclean et al., 2002). Faktor pembatas padi gogo dan sawah tadah hujan adalah cekaman kekeringan. Kekeringan berpengaruh nyata menurunkan tinggi tanaman, jumlah daun, jumlah anakan, panjang malai, bobot 1.000 butir, bobot kering tajuk dan indeks panen, serta meningkatkan persentase gabah hampa (Tubur et al., 2012) . Hasil percobaan Tubur et al. (2012) menunjukkan bahwa perlakuan periode kekeringan berpengaruh nyata menurunkan tinggi tanaman, jumlah daun, jumlah anakan, panjang malai, bobot 1.000 butir, bobot kering tajuk dan indeks pane $n$, serta meningkatkan persentase gabah hampa, namun interaksi kekeringan dan varietas tidak berpengaruh nyata.

Indonesia bercita-cita menjadi lumbung pangan dunia pada tahun 2045 (Sulaiman et al., 2017). Namun terdapat kendala utama yaitu sawah tadah hujan dan gogo yang menjadi salah satu penyumbang produksi padi sangat rawan cekaman kekeringan. Dilaporkan bahwa kekeringan melanda 11 provinsi yang terdapat di 111 kabupaten/kota, 888 kecamatan, dan 4.053 desa pada tahun 2018. Khususnya di Jawa dan Nusa Tenggara selama musim kemarau tersebut sebagian lahan pertanian mengalami puso (Nugroho, 2018).

Teknologi yang paling efektif dan efisien untuk mengatasi cekaman kekeringan adalah dengan penanaman varietas toleran cekaman kekeringan, yakni diawali dengan menyeleksi genotip toleran kekeringan (Serraj et al., 2011). Berdasarkan realita di lapang, apapun paket teknologinya untuk menghadapi masalah kekeringan, tetap bahwa varietas tahan kering selalu direkomendasikan disemua paket teknologi budidaya lahan kering, seperti halnya pada paket informasi kalender tanam terpadu (Ramadhani et al., 2013). Program pemuliaan padi toleran kekeringan dinilai lebih tepat diarahkan untuk menghasilkan varietas galur murni bukan varietas hibrida (Suwarno et al., 2016).

Beberapa pengujian untuk memperoleh varietas toleran kekeringan pada beberapa genotip padi sawah ataupun gogo telah dilakukan di tingkat lapangan dan rumah kaca (Wening \& Susanto, 2014; Kano- 
Nakata et al., 2011; Gómez-Luciano et al., 2012; Suardi \& Abdullah, 2003). Beberapa penelitian telah mengidentifikasi gen pengendali toleransi kekeringan namun masih bersifat putative (Santoso et al., 2013). Sejumlah varietas lokal telah direkomendasikan sebagai tetua tahan kekeringan (Puri et al., 2010) dan sebanyak 34 padi lokal asal Indonesia tahan kekeringan telah berhasil diidentifikasi dan direkomendasikan sebagai tetua persilangan (Sitaresmi et al., 2013). Untuk memperoleh galur-galur tahan kekeringan diperlukan pemahaman interaksi di antara alel untuk toleransi kekeringan dan interaksinya dengan latar belakang ge ne tik (Sandhu \& Kumar, 2017).

Pengujian pada kondisi sawah terkondisikan kekeringan terkontrol masih minim dilakukan. Beberapa penelitian merekomendasikan bahwa hasil skrining kekeringan skala laboratorium atau rumah kaca seperti perlakuan PEG sebaiknya diverifikasi dengan kondisi kekeringan di lapang (Afa et al., 2013). Ditambahkan oleh Shekhar et al. (2017) bahwa seleksi berdasarkan indeks kekeringan akan menghasilkan identifikasi genotip dengan kinerja yang lebih tinggi secara signifikan di bawah kekeringan sedang hingga berat.

Penelitian pada lingkungan cekaman kekeringan skala lapang sangat diperlukan karena mewakili kondisi sebenarnya yang pada kenyataannya adalah kondisi yang dihadapi petani dilapang. Hasil penelitian sebelumnya telah diperoleh galur-galur generasi lanjut (> F8) yang sudah seragam dan perlu dilakukan evaluasi lebih lanjut. Seleksi pada lingkungan kekeringan skala lapang, evaluasi penurunan hasil dan indeks toleransi cekaman kekeringan perlu dilakukan untuk memperoleh galur-galur adaptif kekeringan untuk sawah tadah hujan.

\section{BAHAN DAN METODE}

Penelitian terdiri dari dua kegiatan. Kegiatan ke 1 yaitu penelitian observasi dan seleksi dan kegiatan ke-2 uji lanjut hasil seleksi. Kegiatan ke-1 dilaksanakan di lahan tadah hujan, Ds. Sukamandi, Kec. Ciasem, Subang pada MT1 2016. Sebanyak 135 galur murni dan cek Mekongga (cek rentan) dan Inpari 38 (merupakan VUB padi tadah hujan - cek tahan) diujikan di petak sawah tadah hujan dengan diberi cekaman kekeringan tanpa ulangan. Cekaman lingkungan yang diaplikasikan adalah 1 bulan diberi pengairan dan bulan selanjutnya sampai menjelang panen dikeringkan (dengan mempertahankan kondisi air tanah $\geq 50 \mathrm{~cm}$ dari permukaan tanah). Keterangan Tetua persilangan materi genetik penelitian observasi dan seleksi disajikan pada Tabel 1.

Prosedur pelaksanaan pengujian 135 galur pada kondisi kekeringan diantaranya pemberian pengairan optimum pada 1 bulan pertama setelah tanam dan tanpa pengairan pada bulan ke-2 sampai dengan panen. Umur bibit $21 \mathrm{hss}$, jarak tanam yang digunakan $25 \mathrm{~cm} \times 25 \mathrm{~cm}$ dan pemupukan sesuai rekomendasi PUTS (perangkat uji tanah sawah). Untuk memastikan kondisi kekeringan skala lapang berada pada level air muka tanah berada dibawah perakaran, maka di pasang alat ukur kedalaman air tanah berupa paralon ukur di 3 titik dan ditunjang pengukuran alat irrometer (pengukurkelembaban tanah). Prosedur uji galur toleran terseleksi diantaranya pengairan optimum, umur bibit 21 hss, pemupukan sesuai rekomendasi PUTS, jarak tanam $25 \mathrm{~cm} \times 25 \mathrm{~cm}$. 
Tabel 1. Informasi tetua persilangan dari 135 galur murni padi Tadah Hujan (materi observasi dan seleksi)

\begin{tabular}{|c|c|c|c|}
\hline No & Tetua persilangan & No & Tetua persilangan \\
\hline 1 & $\begin{array}{l}\text { N22/2*AS996- } \\
\text { 9/3*Inpari13 }\end{array}$ & 31 & $\begin{array}{l}\text { IRGC 101969 } \\
\text { [W1744]/Ciheran }\end{array}$ \\
\hline 2 & $\begin{array}{l}\text { IRGC } 100641 \text { [TWC } \\
40-5] \text { / IRGC } 100847 \\
\text { [O. SATIVA/O } \\
\text { NIVARA] }\end{array}$ & 32 & $\begin{array}{l}\text { g } \\
\text { IRGC 100191 } \\
\text { [W0594]/Inpari13 }\end{array}$ \\
\hline 3 & $\begin{array}{l}\text { IR 83142-B-60- } \\
\text { B/Inpari } 10\end{array}$ & 33 & $\begin{array}{l}\text { IRGC 100191 } \\
\text { [W0594]/Inpari14 }\end{array}$ \\
\hline 4 & IR89848/INPARI 13 & 34 & $\begin{array}{l}\text { IR66/Dular//Inpar } \\
\text { i 13///Inpari } 10\end{array}$ \\
\hline 5 & IR89856/CIHERANG & 35 & $\begin{array}{l}\text { N22/2*AS996- } \\
9 / 2 * \text { Ciherang }\end{array}$ \\
\hline 6 & IR89860/CIHERANG & 36 & $\begin{array}{l}\text { Ga ya byeo/Dular// } \\
\text { Inpari } 13 / / / \text { Inpari } \\
10\end{array}$ \\
\hline 7 & IR89860/INPARI 13 & 37 & $\begin{array}{l}\text { Gaya byeo/Dular// } \\
\text { Inpari 13///Inpari } \\
11\end{array}$ \\
\hline 8 & $\begin{array}{l}\text { TNAU } 6484 / \text { Inpari } \\
\text { 13//Inpari } 13\end{array}$ & 38 & $\begin{array}{l}\text { Dular/2*NSIC } \\
\text { Rc160/2*Ciheran } \\
\text { g/Bahbutong }\end{array}$ \\
\hline 9 & $\begin{array}{l}\text { IRGC } 100847 \text { [O. } \\
\text { sativa/O. nivara] / } \\
\text { Inpari } 13 / / \text { Inpari13 }\end{array}$ & 39 & $\begin{array}{l}\text { Jinmibyeo/Nippo } \\
\text { nbare/3*Ciherang } \\
\text { /Wanxian } 78\end{array}$ \\
\hline 10 & HHZ9/INPARI 13 & 40 & $\begin{array}{l}\mathrm{N} 22 / 2 * \text { Ga ya byeo } \\
/ 3 * \text { Ciherang///// } \\
\text { Bahbutong }\end{array}$ \\
\hline 11 & IR89860/INPARI 13 & 41 & $\begin{array}{l}\text { N22/2*Junambye } \\
\text { o/2*Ciherang//// } \\
\text { Lalan/////Batuteg } \\
\text { i }\end{array}$ \\
\hline 12 & $\begin{array}{l}\text { Ha nareumbyeo/Dul } \\
\text { ar }\end{array}$ & 42 & $\begin{array}{l}\text { IRGC104429(G.S } \\
\text { 6069)/Ciherang }\end{array}$ \\
\hline 13 & Gayabyeo/Dular & 43 & $\begin{array}{l}\text { Blok Runti/Inpari } \\
18\end{array}$ \\
\hline 14 & IR89860/INPARI 13 & 44 & $\begin{array}{l}\text { N22/2*Juna mbye } \\
\text { o//2*Ciherang/5/ } \\
\text { Lalan/6/Batutegi/ } \\
\text { 7/Ba rumun }\end{array}$ \\
\hline 15 & $\begin{array}{l}\text { IRGC } 101398 \\
\text { [O.NIVARA/O.SATIV } \\
\text { A]/Ciherang }\end{array}$ & 45 & $\begin{array}{l}\text { Situ Bagendit/IR } \\
83140-B-11-B\end{array}$ \\
\hline 16 & $\begin{array}{l}\text { IRGC 101969 } \\
\text { [W1744]/Inpari13 }\end{array}$ & 46 & HHZ5/INPARI 13 \\
\hline 17 & $\begin{array}{l}\text { IRGC } 104436 \\
\text { [G.S.6075]/ } \\
\text { Ciherang }\end{array}$ & 47 & HHZ5/INPARI 13 \\
\hline 18 & $\begin{array}{l}\text { IRGC } 102475 \\
{[\text { W18]/Inpari13 }}\end{array}$ & 48 & HHZ5/INPARI 13 \\
\hline 19 & $\begin{array}{l}\text { IRGC 101969 } \\
\text { [W1744]/Inpari13 }\end{array}$ & 49 & $\begin{array}{l}\text { |R89848/INPARI } \\
13\end{array}$ \\
\hline 20 & $\begin{array}{l}\text { IRGC } 100847 \text { [O. } \\
\text { sativa/O. nivara] / } \\
\text { Inpari } 13 / / \text { Inpari16 }\end{array}$ & 50 & $\begin{array}{l}\text { IR89856/CIHERAN } \\
\text { G }\end{array}$ \\
\hline
\end{tabular}

\begin{tabular}{|c|c|c|c|}
\hline 21 & Ciherang/IRGC & 51 & IR89856/INPARI \\
\hline & $\begin{array}{l}104846 \text { [G.S. } \\
\text { 10551]//Ciherang }\end{array}$ & & 13 \\
\hline 22 & $\begin{array}{l}\text { IRGC } 101969 \\
{[\text { W1744]/Inpari14 }}\end{array}$ & 52 & $\begin{array}{l}\text { Ciherang/WTR1// } \\
\text { Ciherang/Zhongh } \\
\text { ua } 1\end{array}$ \\
\hline 23 & $\begin{array}{l}\text { IRGC } 101969 \\
\text { [W1744]/Inpari15 }\end{array}$ & 53 & $\begin{array}{l}\text { Ciherang/ZX } \\
\text { 117//Ciherang }\end{array}$ \\
\hline 24 & $\begin{array}{l}\text { IRGC101969 } \\
{[\text { W1744]/In pari13 }}\end{array}$ & 54 & $\begin{array}{l}\text { Ciherang/Wanxia } \\
\text { n } 77 / / \text { Ciherang }\end{array}$ \\
\hline 25 & $\begin{array}{l}\text { IRGC 101983 } \\
\text { [W1770]/Ciherang }\end{array}$ & 55 & $\begin{array}{l}\text { Ciherang/Huangh } \\
\text { uazhan//Ciherang } \\
\text { /Zhonghua } 1\end{array}$ \\
\hline 26 & $\begin{array}{l}\text { IRGC 100191 } \\
\text { [W0594]/Inpari13 }\end{array}$ & 56 & $\begin{array}{l}\text { Ciherang/ZX } \\
\text { 117//Ciherang/W } \\
\text { TR1 }\end{array}$ \\
\hline 27 & $\begin{array}{l}\text { IRGC 100191 } \\
\text { [W0594]/In pari14 }\end{array}$ & 57 & $\begin{array}{l}\text { Ciherang/Zhongzu } \\
14\end{array}$ \\
\hline 28 & $\begin{array}{l}\text { IRGC 100191 } \\
\text { [W0594]/Inpari13 }\end{array}$ & 58 & Ciherang/ZX 117 \\
\hline 29 & $\begin{array}{l}\text { Ciherang/IRGC } \\
104846 \text { [G.S. } \\
\text { 10551]//Ciherang }\end{array}$ & 59 & Ciherang/WTR1 \\
\hline 30 & $\begin{array}{l}\text { IRGC 100191 } \\
\text { [W0594]/Inpari15 }\end{array}$ & & \\
\hline
\end{tabular}

Kegiatan ke-2yaitu uji lanjut galur-gal ur hasil seleksi penelitian MT1 2016. Kegiatan dilaksanakan di lahan sawah tadah hujan Ds. Cianting, Kec. Sukatani, Purwakarta pada MT1 2017. Materi genetik yang digunakan pada penelitian evaluasi lanjutan adalah sebanyak 19 galur tahan kekeringan (hasil seleksi berdasarkan karakter daun menggulung dan karakter hasil) dengan 2 cek (Mekongga-cek rentan dan Inpari 38 cek tahan).

Kegiatan ke-2 dilakukan menggunakan Rancangan Acak Kelompok dengan 3 ulangan dengan cek Ciherang (cek tambahan), Mekongga, dan Inpari 38 Tadah Hujan, sehingga total perlakuan adalah 19 terpilih pada kegiatan ke-1 dan 2 cek.

Karakter pengamatan pada kegiatan ke-1 diantaranya: skor penggulungan daun disajikan pada Tabel 2 (mengikuti SES IRRI tahun 2013), vigor yang diukur pada umur 3 minggu setelah tanam (Tabel 3), bobot gabah per rumpun yang selanjutnya dikonversi ke ton/ha. Pengamatan 
dilakukan pula terhadap kondisi muka air tanah dan pengukuran irrometer untuk memastikan kondisi kekeringan terjaga pada kegiatan ke-1.

Tabel 2. Skor penggulungan daun akibat stress kekeringan

\begin{tabular}{cl}
\hline Skala & Kriteria \\
\hline 0 & Daun sehat \\
1 & Daun mulai melipat(dangkal) \\
3 & Daun melipat (bentuk V) \\
5 & $\begin{array}{l}\text { Daun menggulung namun sisi } \\
\text { daun belum saling menyentuh } \\
\text { (bentuk U) } \\
\end{array}$ \\
& $\begin{array}{l}\text { Daun menggulung dan sisi daun } \\
\text { saling menyentuh (bentuk 0) } \\
9\end{array}$ \\
\hline
\end{tabular}

Karakter pengamatan kegiatan ke-2 diantaranya : tinggi tanaman, jumlah anakan produktif, jumlah gabah isi per malai, jumlah gabah hampa per malai, persentase pengisian gabah, bobot 1000 butir, bobot gabah per 3 rumpun, dan hasil per hektar. Karakter diamati pada kegiatan uji lanjutan diantarnya: tinggi tanaman, jumlah anakan produktif, jumlah gabah isi per malai, jumlah gabah hampa per malai, persentase pengisian gabah, bobot 1000 butir, bobot gabah per 3 rumpun, dan hasil perhektar.

Analisis yang digunakan adalah penurunan hasil, indeks toleransi kekeringan, dan analisis varian. Analisis varian dilakukan pada evaluasi 19 galur untuk mengetahui keunggulan daya hasil dibandingkan cek. Apabila terdapat perbedaan yang nyata pada suatu karakter, maka diuji lanjut dengan uji DMRT 5\% untuk mengetahui perbedaan antar galur dan ce $k$. Analisis dilakukan dengan menggunakan perangkat lunak STAR tool, Minitab versi 14, dan Ms. Excel.
Tabel 3. Skala vigor tanaman fase vegetatif

\begin{tabular}{|c|c|}
\hline Skala & Kriteria vigor \\
\hline 1 & $\begin{array}{l}\text { Sangat kuat (pertumbuhan } \\
\text { sangat cepat; tanaman pada } 5-6 \\
\text { tahap daun dan memiliki } 2 \text { atau } \\
\text { lebih anakan dalam mayoritas } \\
\text { populasi) }\end{array}$ \\
\hline 3 & $\begin{array}{l}\text { Kuat (cepat tumbuh; tanaman } \\
\text { pada tahap } 4-5 \text { daun dan } \\
\text { memiliki } 1-2 \text { anakan di mayoritas } \\
\text { populasi) }\end{array}$ \\
\hline 5 & $\begin{array}{l}\text { Normal (tanaman pada tahap } 4 \\
\text { daun) }\end{array}$ \\
\hline 7 & $\begin{array}{l}\text { Lemah (tanaman } r \text { agak } \\
\text { terhambat; 3-4 daun; populasi } \\
\text { tipis; tidak ada pembentukan } \\
\text { anakan) }\end{array}$ \\
\hline 9 & $\begin{array}{l}\text { sangat lemah (pertumbuhan } \\
\text { terhambat; daun menguning) }\end{array}$ \\
\hline
\end{tabular}

Penurunan hasil $(\Delta Y)=Y_{o}-Y_{s}$ Indeks sensitivitas cekaman kekeringan (ISK) menurut Fischer dan Maurer (1978) :

$$
\text { ISK }=\left(1-\frac{Y_{Q_{R}}}{Y_{o_{1}}}\right) /\left(1-\frac{\bar{Y}_{\mathrm{g}}}{\bar{Y}_{\mathrm{Q}}}\right)
$$

Keterangan :

$Y_{\text {oi }}=$ Daya hasil dari suatu genotype i pada kondisi optimum,

$Y_{\bar{a} i}=$ Daya hasil dari suatu genotip i pada kondisi stres kekeringan lapang

$\overline{Y_{o}}=$ Daya hasil rata-rata seluruh genotip pada kondisi optimum

$\bar{Y}_{s}=$ Daya hasil rata-rata seluruh genotip apda kondisi stress kekeringan

Kriteria untuk menentukan tingkat toleransi terhadap cekaman kekeringan adalah jika nilai ISK $\leq 0.5$ maka genotip tersebut toleran, jika $0.5<$ ISK $\leq 1.0$ maka genotip tersebut agak toleran (moderat), dan jika ISK > 1.0 maka genotip tersebut sensitif (Widyastuti et al., 2016). 


\section{HASIL DAN PEMBAHASAN}

Kondisi umum tanah pada fase stres kekeringan ditunjukkan berdasarkan data kedalaman keberadaan air dari permukaan tanah. Rata-rata kedalam keberadaan air tanah adalah sedalam $62,5 \mathrm{~cm}$ dari permukaan tanah dan rata-rata angka nilai irrometer adalah 67 centibar/Kpa (Tabel 4). Informasi tingkat kekeringan menunjukkan bahwa semakin tinggi nilai irrometer menandakan semakin kering kondisi tanah sawah karena semakin dalam keberadaan air dalam tanah. Keberadaan air dalam tanah sedalam $62,5 \mathrm{~cm}$ menandakan bahwa keberadaan air jauh di bawah sebaran perakaran (kedalaman perakaran padi ratarata $30 \mathrm{~cm}$ ). Dengan demikian, kondisi kekeringan skala lapang pada penelitian tercapai.

Tabel 4. Informasi tingkat kekeringan ratarata lahan pada fase kering (2 bulan setelah tanam sampai dengan panen pada kegiatan seleksi

\begin{tabular}{lcc}
\hline & $\begin{array}{c}\text { Kedalam air } \\
\text { tanah }(\mathrm{cm})\end{array}$ & $\begin{array}{c}\text { Irrometer } \\
\text { (centibar/Kpa) }\end{array}$ \\
\hline Titik 1 & 60,0 & 61,0 \\
Titik2 & 65,0 & 72,0 \\
Titik3 & 62,5 & 68,0 \\
Rata-rata & 62,5 & 67,0 \\
\hline
\end{tabular}

Sebanyak 135 galur memberikan respon yang bervariasi terhadap kondisi kekeringan skala lapang. Pada sebaran data karakter bobot gabah 3 rumpun (Gambar 1), diperoleh 90 galur mati kekeringan dan tidak berproduksi dan sisanya mampu hidup dan berproduksi. Sebanyak 19 galur terbaik berhasil diperoleh dari total 135 galur yang diujikan pada kondisi stress kekeringan (intensitas seleksi 13,9\%).

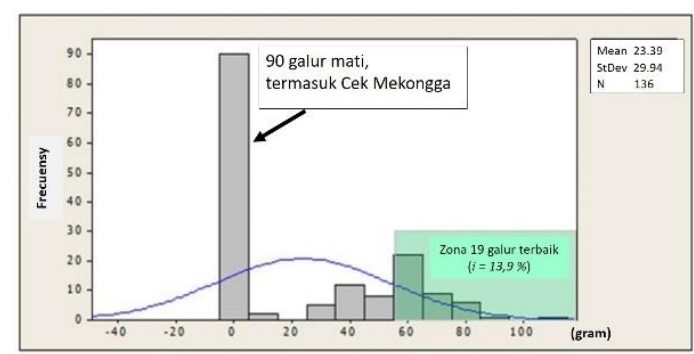

Gambar 1. Sebaran data karakter bobot gabah per 3 rumpun dari 136 galur/varieta s (termasuk Mekongga) pada kondisi stress kekeringan

Sebanyak 19 galur diseleksi berdasarkan kriteria skor menggulung 1 (sangat toleran), vigor dan umur masak fisiologis (Tabel 5). Galur-galur terpilih memiliki skor menggulung 1 . Artinya pada kondisi stres kekeringan, kondisi daun tidak menggulung dan tidak mengalami gejala daun mengering. Vigor galur terpilih memiliki skor 3 yang artinya kuat (IRRI, 2013). Sejalan dengan rekomendasi ( $\mathrm{Ai}$ et al., 2010), bahwa karakter vigor dapat dijadikan salah satu kriteria seleksi untuk cekmaan kekeringan.

Evaluasi terhadap 19 galur toleran menunjukkan penurunan hasil rata-rataakibat kekeringan skala lapang sebanyak $1,08 \mathrm{t} \mathrm{ha}^{-1}$. Galuryangmengalami penurunan hasil paling besar adalah BP20118c-SKI-2-2-3-4-PWK-1-SKI1 yakni sebesar 1,9 t ha $^{-1}$ dan yang paling kecil penurunan hasil adalah BP18406c-JK-1-IND-0SKI-3-PWK-2-SKI-1 yakni sebesar 0,09 $\mathrm{t} \mathrm{ha}^{-1}$ (Tabel6).

Galur-galur yang diuji memiliki indeks sensitivitasterhadap cekaman kekeringan ratarata sebesar 0.19. Rentang ISK galur-galur yaitu $0,02-0,37$ artinya ISK $\leq 0,5$ maka genotip tersebut toleran terhadap cekaman kekeringan. MenurutAkbar et al. (2018), nilai ISK yang rendah menunjukkan bahwage notip yang diuji pada kondisi sub optimum tidak menunjukkan penurunan yang besarsehingga 
dapat dikatakan genotip tersebut toleran. Hasil pengujian memperoleh 4 galurtoleran dengan nilai ISK $\leq$ 0,5 yakni BP17586-2-0-J K-3-IND-2SKI-

Tabel 5. Tingkat ketahanan 19 galur terbaik pada kondisi stres kekeringan

\begin{tabular}{|c|c|c|c|c|}
\hline No & Nama Galur & $\begin{array}{c}\text { Skor } \\
\text { meng } \\
\text { gulun } \\
\mathbf{g}\end{array}$ & $\begin{array}{l}\text { V } \\
\text { i } \\
\text { g } \\
\text { o } \\
\text { r }\end{array}$ & Umur (hss) \\
\hline 1 & $\begin{array}{l}\text { BP17586-2-0-JK-3-IND- } \\
\text { 2-SKI-10-PWK-1-SKI-2 }\end{array}$ & 1 & 3 & 80 \\
\hline 2 & $\begin{array}{l}\text { BP18336-1-2-JK-2-IND- } \\
\text { 1-SKI-8-PWK-3-SKI-3 }\end{array}$ & 1 & 3 & 89 \\
\hline 3 & $\begin{array}{l}\text { BP18354-1-1-JK-1-IND- } \\
\text { 1-SKI-3-PWK-1-SKI-1 }\end{array}$ & 1 & 3 & 94 \\
\hline 4 & $\begin{array}{l}\text { BP18354-1-2-JK-3-IND- } \\
\text { 1-SKI-3-PWK-1-SKI-1 }\end{array}$ & 1 & 3 & 94 \\
\hline 5 & $\begin{array}{l}\text { BP18360-1-3-JK-3-IND- } \\
\text { 1-SKI-1-PWK-1-SKI-1 }\end{array}$ & 1 & 3 & 94 \\
\hline 6 & $\begin{array}{l}\text { BP18360-2-1-JK-3-IND- } \\
\text { 1-SKI-8-PWK-1-SKI-4 }\end{array}$ & 1 & 3 & 89 \\
\hline 7 & $\begin{array}{l}\text { BP18360-2-1-JK-3-IND- } \\
\text { 1-SKI-8-PWK-2-SKI-2 }\end{array}$ & 1 & 3 & 89 \\
\hline 8 & $\begin{array}{l}\text { BP18360-2-3-JK-1-IND- } \\
\text { 1-SKI-10-PWK-2-SKI-1 }\end{array}$ & 1 & 3 & 89 \\
\hline 9 & $\begin{array}{l}\text { BP18360-2-3-JK-1-IND- } \\
\text { 1-SKI-4-PWK-2-SKI-1 }\end{array}$ & 1 & 3 & 89 \\
\hline 10 & $\begin{array}{l}\text { BP18360-2-3-JK-1-IND- } \\
\text { 1-SKI-7-PWK-2SKI-1 }\end{array}$ & 1 & 3 & 89 \\
\hline 11 & $\begin{array}{l}\text { BP18406c-JK-1-IND-0- } \\
\text { SKI-3-PWK-2-SKI-1 }\end{array}$ & 1 & 3 & 80 \\
\hline 12 & $\begin{array}{l}\text { BP20118c-SKI-2-2-3-10- } \\
\text { PWK-1-SKI-1 }\end{array}$ & 1 & 3 & 89 \\
\hline 13 & $\begin{array}{l}\text { BP20118c-SKI-2-2-3-3- } \\
\text { PWK-2-SKI-1 }\end{array}$ & 1 & 3 & 89 \\
\hline 14 & $\begin{array}{l}\text { BP20118c-SKI-2-2-3-4- } \\
\text { PWK-1-SKI-1 }\end{array}$ & 1 & 3 & 89 \\
\hline 15 & $\begin{array}{l}\text { BP20118c-SKI-2-2-3-7- } \\
\text { PWK-2-SKI-1 }\end{array}$ & 1 & 3 & 89 \\
\hline 16 & $\begin{array}{l}\text { BP20118c-SKI-2-2-3-8- } \\
\text { PWK-3-SKI-1 }\end{array}$ & 1 & 3 & 93 \\
\hline 17 & $\begin{array}{l}\text { BP20118c-SKI-2-2-3-9- } \\
\text { PWK-2-SKI-1 }\end{array}$ & 1 & 3 & 93 \\
\hline 18 & $\begin{array}{l}\text { BP29308-1-CRB-0-SKI- } \\
\text { 0-1-PWK-1-SKI-3 }\end{array}$ & 1 & 3 & 89 \\
\hline \multirow[t]{2}{*}{19} & $\begin{array}{l}\text { BP29308-1-CRB-0-SKI- } \\
\text { 0-8-PWK-3-SKI-1 }\end{array}$ & 1 & 3 & 89 \\
\hline & Rata - rata & 1 & 3 & 89.26 \\
\hline
\end{tabular}

10-PWK-1-SKI-2 (ISK0,49), BP18354-1-2-JK-3IND-1-SKI-3-PWK-1-SKI-1 (ISK0,49), BP $18360-$ 2-3-JK-1-IND-1-SKI-7-PWK-2SKI-1 (ISK 0,16), dan BP18406c-JK-1-IND-0-SKI-3-PWK-2-SKI-1 (ISK 0,1). Semakin rendah nilia indeks sensitivitas terhadap cekaman kekeringan maka semakin bagus toleransinya te rhadap cekamantersebut. Berdasarkan hal te rs ebut, yang memiliki toleransi paling baik adalah BP18406c-JK-1-IND-0-SKI-3-PWK-2-SKI-1 (galur nomor 11) (Tabel6).

Tabel 6. Penurunan hasil dan sensitivitas cekamankekeringan (ISK)

\begin{tabular}{cccccc}
\hline No & Yol & Ys & $\Delta Y$ & ISK & Kriteria \\
\hline $\mathbf{1}$ & $\mathbf{3 . 7 8}$ & $\mathbf{3 . 3 5}$ & $\mathbf{0 . 4 3}$ & $\mathbf{0 . 4 9}$ & Toleran \\
$\mathbf{2}$ & 5.43 & 3.77 & 1.66 & 1.31 & Sensitif \\
3 & 4.45 & 3.35 & 1.09 & 1.06 & Sensitif \\
$\mathbf{4}$ & $\mathbf{4 . 7 7}$ & $\mathbf{4 . 2 3}$ & $\mathbf{0 . 5 4}$ & $\mathbf{0 . 4 9}$ & Toleran \\
5 & 5.04 & 3.87 & 1.18 & 1.00 & Sensitif \\
6 & 3.94 & 3.37 & 0.57 & 0.62 & Moderat \\
7 & 4.94 & 3.30 & 1.65 & 1.42 & Sensitif \\
8 & 4.36 & 3.41 & 0.95 & 0.93 & Sensitif \\
9 & 4.18 & 3.56 & 0.63 & 0.64 & Moderat \\
$\mathbf{1 0}$ & $\mathbf{4 . 0 9}$ & $\mathbf{3 . 9 4}$ & $\mathbf{0 . 1 5}$ & $\mathbf{0 . 1 6}$ & Toleran \\
$\mathbf{1 1}$ & $\mathbf{4 . 0 2}$ & $\mathbf{3 . 9 3}$ & $\mathbf{0 . 0 9}$ & $\mathbf{0 . 1 0}$ & Toleran \\
12 & 5.12 & 3.42 & 1.70 & 1.42 & Sensitif \\
13 & 5.03 & 3.25 & 1.78 & 1.52 & Senisitif \\
14 & 5.13 & 3.24 & 1.90 & 1.58 & Senisitif \\
15 & 4.75 & 3.19 & 1.56 & 1.41 & Senisitif \\
16 & 4.44 & 3.36 & 1.08 & 1.04 & Senisitif \\
17 & 4.91 & 3.26 & 1.65 & 1.44 & Senisitif \\
18 & 4.80 & 3.57 & 1.23 & 1.10 & Senisitif \\
19 & 4.79 & 4.07 & 0.72 & 0.64 & Moderat \\
Rata2 & 4.63 & 3.55 & 1.08 & & \\
\hline Keteran & & \\
\hline
\end{tabular}

Keterangan : $Y_{0}=$ hasil pada kondisi optimum, $Y_{s}$ = hasil pada kondisi cekaman kekeringan lapang, ISK = indeks sensitivitas cekaman kekeringan

Afa et al. (2013) menyatakan bahwa Genotip yang memiliki bobot gabah per rumpun dan indeks panen yang tinggi berimplikasi padanilai indeks toleransi yang tinggi dan indekskepekaanyang rendah. Praba et al. (2009) menyatakan bahwa fase kritis pada saat cekaman kekeringan adalah fase mulai pembungaan. Cekamankekeringan pada fase tersebutakan menyebabkan penurunan hasil yang luar biasa pada genotip tidak toleran. 
Berdasarkan data umur mas ak fisiologis pada Tabel 3 dan 5, menunjukkan bahwa 19 galur terseleksi mampu mentoleransi cekaman kekeringan dengan caramempercepat masa hidup dengantetap mempertahankan potensi hasil. Penelitan menunjukkan bahwa cekaman kekeringan sangat mempengaruhi umur masak fisiologis. Kondisi cekaman kekeringan membuatgalur-galur lebih mempercepatmasa hidupnya. Umur pada kondisi optim um lebih panjang dibandingkan padakondisi cekaman kekeringan.

Sembilan belas galur toleran kekeringan yang dievaluasi pada kondisi optimum sawah tadah hujan masih memiliki keraga man pada karakter tinggi tanaman dan bobot 1000 butir (gram). Galur yang memiliki postur paling tinggi adalah BP18360-2-1-JK-3-IND-1-SKI-8-PWK-2SKI-2 yakni $114 \mathrm{~cm}$ dan yang paling pendek adalah BP17586-2-0-JK-3-IND-2-SKI-10-PWK-1SKI-2 yakni $98.27 \mathrm{~cm}$. Sedangkan galur BP29308-1-CRB-0-SKI-0-8-PWK-3-SKI-1 memiliki bobot 1000 butiryang berbeda nyata dengan BP18360-2-3-JK-1-IND-1-SKI-7-PWK2SKI-1 yakni masing-masing $29.47 \mathrm{gr}$ dan 21.94 gr (Tabel 7).

Tabel 7. Keragaan agronomis galur - galur toleran kekeringan hasil evaluasi galur terseleksi pada lahan sawah tadah hujan kondisi optimum

\begin{tabular}{|c|c|c|c|c|c|c|c|c|}
\hline $\begin{array}{l}\text { No } \\
\text { Galur }\end{array}$ & UF & TT & JAP & $\mathrm{GI} / \mathrm{malai}$ & $\begin{array}{l}\mathrm{GH} / \\
\text { malai }\end{array}$ & SS\% & B1000 & Y \\
\hline 1 & 108 & $98,27 b$ & 14,57 & 141,33 & 50,00 & 73,50 & $25,13 \mathrm{abc}$ & 3,78 \\
\hline 2 & 106 & $109,27 a b$ & 13,60 & 154,33 & 45,00 & 77,85 & $27,43 a b c$ & 5,43 \\
\hline 3 & 101 & $108,60 a b$ & 14,07 & 155,67 & 35,00 & 81,89 & $26,83 a b c$ & 4,45 \\
\hline 4 & 109 & $104,80 a b$ & 15,87 & 152,33 & 21,67 & 87,60 & $23,79 a b c$ & 4,77 \\
\hline 5 & 106 & $113,40 a$ & 15,53 & 166,33 & 27,33 & 86,01 & $26,81 \mathrm{abc}$ & 5,05 \\
\hline 6 & 109 & $110,67 a$ & 13,00 & 154,00 & 39,67 & 79,34 & $23,61 \mathrm{abc}$ & 3,94 \\
\hline 7 & 109 & $114,00 \mathrm{a}$ & 14,27 & 154,33 & 51,00 & 75,36 & $23,70 a b c$ & 4,94 \\
\hline 8 & 104 & $110,53 a$ & 14,73 & 170,67 & 56,67 & 76,19 & $22,86 \mathrm{abc}$ & 4,37 \\
\hline 9 & 101 & $110,60 \mathrm{a}$ & 14,27 & 164,00 & 45,33 & 78,45 & $23,37 a b c$ & 4,18 \\
\hline 10 & 109 & $112,73 a$ & 21,20 & 158,67 & 48,33 & 76,53 & $21,94 \mathrm{bc}$ & 4,09 \\
\hline 11 & 100 & $105,67 a b$ & 14,67 & 115,67 & 35,67 & 76,38 & $26,70 \mathrm{abc}$ & 4,02 \\
\hline 12 & 106 & $108,07 a b$ & 14,93 & 155,00 & 42,67 & 83,66 & $25.69 a b c$ & 5,12 \\
\hline 13 & 103 & $111,20 a$ & 14,07 & 158,33 & 46,00 & 77,56 & $24,44 a b c$ & 5,03 \\
\hline 14 & 103 & $106,00 \mathrm{ab}$ & 13,53 & 164,33 & 50,00 & 76,43 & 24,11 abc & 5,13 \\
\hline 15 & 103 & $106,40 a b$ & 14,73 & 151,33 & 44,00 & 78,27 & $26,47 a b c$ & 4,75 \\
\hline 16 & 102 & $106,27 a b$ & 13,73 & 146,33 & 55,33 & 72,55 & $24,91 \mathrm{abc}$ & 4,44 \\
\hline 17 & 104 & $106,73 a b$ & 15,40 & 157,67 & 35,33 & 81,83 & $25,93 \mathrm{abc}$ & 4,91 \\
\hline 18 & 103 & $106,87 a b$ & 15,33 & 150,00 & 46,67 & 75,54 & $26,48 \mathrm{abc}$ & 4,80 \\
\hline 19 & 101 & $108,67 a b$ & 15,33 & 152,00 & 40,00 & 78,85 & $29,47 a$ & 4,79 \\
\hline 20 & 104 & $103,33 a b$ & 15,13 & 141,33 & 23,33 & 85,82 & $26,60 \mathrm{abc}$ & 4,15 \\
\hline 21 & 104 & $109,93 a b$ & 14,80 & 174,00 & 39,00 & 81,62 & $28,11 \mathrm{abc}$ & 4,53 \\
\hline 22 & 104 & $106,75 a b$ & 14,07 & 165,33 & 26,67 & 85,98 & 25,47 a bc & 4,11 \\
\hline
\end{tabular}

Ke te rangan: Huruf yang berbeda dibelakang angka antargalur menunjukkan perbedaan yang nyata pada uji lanjut DMRT taraf $5 \%$. UF = umur masak fisiologis (hss), TT = tinggi tanaman (cm), JAP = jumlah anakan produktif, $\mathrm{Gl}=$ gabah isi, $\mathrm{GH}=$ ga bah hampa, SS = persentase pengisian gabah, B1000 = bobot 1000 butir (gram), $Y=$ potensi hasil (ton/ha). Cek No 20 = Ciherang, Cek No 21 = Inpari 38 Tadah Hujan, Cek No 22 = Mekongga. 
Analisis keragaman menunjukkan bahwa potensi hasil ke 19 galur toleran hasil seleksi tidak berbeda nyata satu dengan lain. Cek Inpari 38 Tadah Hujan (4,53 t ha $\left.{ }^{-1}\right)$ memperlihatkan potensi hasil lebih tinggi dibandingkan Ciherang $\left(4,5 \mathrm{t} \mathrm{ha}^{-1}\right)$ dan Mekongga $\left(4,11 \mathrm{t} \mathrm{ha}^{-1}\right)$. Walaupun tidak berbeda nyata pada kondisi irigasi optimum di lahan tadah hujan namun terdapat galur-galur yang memiliki potensi hasil lebih tinggi dari Inpari 38 Tadah Hujan. Berdasarkan nilai potensi hasil diperoleh galur-galur yang memiliki dayahasil $>5 \mathrm{t} \mathrm{ha}^{-1}$, diantaranya: galur No 2 yaitu BP18336-1-2-JK-2-IND-1-SKI-8-PWK3-SKI-3 (5,43 tha-1 $)$, galur No 5 yaitu BP183601-3-JK-3-IND-1-SKI-1-PWK-1-SKI-1 (5,05 tha-1 ${ }^{-1}$, galur No12 yaitu BP20118c-SKI-2-2-3-10-PWK1-SKI-1 (5,12 t ha-1), galur No 13 yaitu BP20118c-SKI-2-2-3-3-PWK-2-SKI-1 (5,03 tha$\left.{ }^{1}\right)$, dan galur No14 yaitu BP20118c-SKI-2-2-3-4PWK-1-SKI-1 (5,13 tha-1).

Apabila dilakukan pemilihan galur-galur terbaik berdasarkan seleksi bertahap yakni karakter utama adalah daya hasil dan karakter kedua adalah indeks sensitivitas cekaman kekeringan, dengan menggunakan metode filter pada Ms. Excel, maka diperoleh 1 gal ur terbaik yang memiliki potensi hasil diatas ratarata cek Inpari38Tadah Hujan dan toleran si terhadap cekamankekeringan dengan baik . galur nomor $4 \rightarrow$ BP18354-1-2-JK-3-IND-1-SK I3-PWK-1-SKI-1 ( $Y=4,77 \mathrm{t} \mathrm{ha}^{-1}$, ISK $=0,49$. diperoleh pula 3 galur harapan yang mampu berproduksi setara Inpari 38 yaitu Galu r-galu r tersebut yaitu galur nomor $11 \rightarrow$ BP 18406cJK-1-IND-0-SKI-3-PWK-2-SKI-1 (Ys=3,93 t ha ${ }^{-1}$, ISK $=0,10$ ), galurnomor $10 \rightarrow$ BP18360-2-3-JK1-IND-1-SKI-7-PWK-2SKI-1 (Ys $=3,94 \mathrm{t} \mathrm{ha}^{-1}$, ISK $=0,16)$. Dengan menggunakan dua karakter seleksi ini, maka 1 galur yang terseleksi diharapkan berdaya hasil tinggi dan lebih tinggi dari cek Inpari38Tadah Hujanserta memiliki kekuatan mempertahankan potensi hasil dengan baik pada kondisi cekaman kekeringan. Galur nomor 11 memiliki ISK paling baik dan umur panen lebih genjah 4 hari dari Inpari 38 .

\section{SIMPULAN}

1. Seleksi berdasarkan kriteria daun menggulung pada 135 galur yang diuji telah dilakukan dan diperoleh 19 galur toleran kekeringan skala lapang pada pengujian (Irrometer 62-71 centibar/Kpa) dan Mekongga mati pada kondisi stress kekeringan.

2. Diperoleh 4 galur toleran yaitu BP175862-0-JK-3-IND-2-SKI-10-PWK-1-SKI-2 (ISK 0,49), BP18354-1-2-JK-3-IND-1-SKI-3-PWK1-SKI-1 (ISK0,49), BP18360-2-3-JK-1-IND-1SKI-7-PWK-2SKI-1 (ISK 0.16), dan BP18406cJK-1-IND-0-SKI-3-PWK-2-SKI-1 (ISK0.1).

3. Galur BP18354-1-2-JK-3-IND-1-SKI-3-PWK1-SKI-1 $\left(\mathrm{Y}=4,77 \mathrm{t} \mathrm{ha}^{-1}\right)$ adalah galur terbaik yang memiliki potensi hasil tinggi lebih baik dari cek Inpari 38 Tadah Hujan dan memiliki toleransi terhadap cekaman keekringan. Galur ini poten sial untuk diuji lebih lanjut dan dikembangkan di sawah tadah hujan.

\section{UCAPAN TERIMAKASIH}

Terimakasih kepada anggaran penelitian DIPA 2017 yang telah membiayai penelitian ini. Tak lupa diucapkan terimakasih kepada petani kooperator, penyuluh BPP Kec. Sukatani, Dinas Pertanian Purwakarta, dan teknisi lapang yang telah membantu selama penelitian.

\section{DAFTAR PUSTAKA}

Afa, L. O., Purwoko, B. S., Junaedi, A., Haridjaja, O., \& Dewi, I. S. (2013). Deteksi Dini Toleransi Padi Hibrida terhadap Kekeringan menggunakan 
PEG 6000 Early Detection of Hybrid Rice Tolerance to Drought Using PEG 6000. Jurnal Agronomi Indonesia, 41(1), 9-15.https://doi.org/10.24831/ jai.v41i1.7070

Ai, N.S., Tondais S.M., \& B. R. (2010). Evaluasi Indikator Toleransi Cekaman Kekeringan Pada Fase Perkecambahan Padi (Oryza Sativa L.). Jurnal Biologi, 14(2),50-54.https://doi.org/10.24843/ jbiounud

Akbar, M. R., Purwoko, B. S., Dewi, I. S., \& Suwarno, D. W. B. (2018). Penentuan Indeks Seleksi Toleransi Kekeringan Galur Dihaploid Padi Sawah Tadah Hujan pada Fase Perkecambahan. JurnalAgronomi Indonesia (Indonesian Journal of Agronomy), 46(2), 133. https://doi.org/10.24831/jai.v46i2.190 86

Gómez-Luciano, L. B., Su, S.-H., Wu, C.-W., \& Hsieh, C.-H. (2012). Establishment of a Rapid Screening Method for Drought Tolerance of Rice Genotypes at Seedling Stage. Journal of International Cooperation, 7(2), 107122. Retrieved from http://www.researchgate.net/publicat ion/258794979_Establishment_of_a_R apid_Screening_Method_for_Drought _Tolerance_of_Rice_Genotypes_at_Se edling_Stage/file/72e7e52a7ab69db32 6.pdf.

IRRI. (2013). Standard Evaluation System for Rice. International Rice Research Instiitute, June, 55. https://doi.org/10.1063/1.1522164

Kano-Nakata, M., Inukai, Y., Wade, L. J., Siopongco, J. D., \& Yamauchi, A. (2011). Root development, water uptake, and shoot dry matter production under water defi cit conditions in two cssls of rice: Functional roles of root plasticity. Plant Production Science, 14(4), 307-
317.

https://doi.org/10.1626/pps.14.307

Nugroho, S. P. (2018). 4,87 Juta Jiwa Penduduk Terdampak Kekeringan Yang Tersebar Di 4.053 Desa. BNPB Editorial. file:///D:/Wage 2020/KTI wage 2020/J. Agrotek UIN/Literatur 3654-20259-2-ED2/Nugroho

2018.html

Praba, M. L., Cairns, J. E., Babu, R. C., \& Lafitte, H. R. (2009). Identification of physiological traits underlying cultivar differences in drought tolerance in rice and wheat. Journal of Agronomy and Crop Science, 195(1), 30-46. https://doi.org/10.1111/j.1439037X.2008.00341.x

Ramadhani, F., Runtunuwu, E., \& Syahbuddin, H. (2013). Sistem Teknologi Informasi Kalender Tanam Terpadu. Informatika Pertanian, 22(2), 103.https://doi.org/10.21082/ip.v22n 2.2013.p103-112

Rohman, A., Helmiyati, S., Hapsari, M., \& Setyaningrum, D. L. (2014). Rice in health and nutrition. International Food Research Journal, 21(1), 13-24. Retrieved from https://www.researchgate.net/publica tion/287284991_Rice_in_health_and_ nutrition

Sandhu, N., \& Kumar, A. (2017). Bridging the rice yield gaps under drought: QTLs, genes, and their use in breeding programs. Agronomy, 7(2), 1-27. https://doi.org/10.3390/agronomy702 0027

Serraj, R., McNally, K. L., Slamet-Loedin, I., Kohli, A., Haefele, S. M., Atlin, G., \& Kumar, A. (2011). Drought resistance improvement in rice: An integrated genetic and resource management strategy. Plant Production Science, 14(1),1-14. https://doi.org/10.1626/p 
ps.14.1

Shekhar, H., Bidhan, G., \& Viswavidyalaya, C. K. (2017). Drought Tolerance Indices for Screening Some of Rice Genotypes. International Journal of Advanced Biological Research, 7(2017), 671-674. Retrieved from https://www.researchgate.net/publica tion/321714630

Sitaresmi, T., Wening, R. H., Rakhmi, A. T., Yunani, N., \& Susanto, U. (2013). Pemanfaatan Plasma Nutfah Padi Varietas Lokal dalam Perakitan Varietas Unggul. Iptek Tanaman Pangan, 8(1), 22-30. Retrieved from http://ejurnal.litbang.pertanian.go. id/index.php/ippan/article/view/25 55

Suardi, D., \& Abdullah, B. (2003). Padi Liar Tetua Toleran Kekeringan. Buletin Plasma Nutfah, 9(1), 33-38. Retrieved from http://ejurnal.litbang.pertanian.go.id/i ndex.php/bpn/article/view/6041/5235

Sulaiman, A. A., Simatupang, P., Las, I., Hermanto, Kariyasa, I. K., Syahyuti, Sumaryanto, S., Suwandi, \& Subagyono, K. (2017). Sukses Swasembada Indonesia Menjadi Lumbung Pangan Dunia 2045 (T. Sudaryanto \& Hermanto (eds.); 1st ed.). Perpustakaan Sekjen Kementan. Retrieved from http://repository.pertanian.go.id/hand le/123456789/8623

Suwarno, P. M., Wirnas, D., \& Junaedi, D. A.
(2016). Kendali Genetik Toleransi Kekeringan pada Padi Sawah (Oryza sativa L.). Jurnal Agronomi Indonesia (Indonesian Journal of Agronomy), 44(2), 119.

https://doi.org/10.24831/jai.v44i2.134 77

Tubur, H. W., Chozin, M. A., Santosa, E., \& Junaedi, A. (2012). Respon Agronomi Varietas Padi terhadap Periode Kekeringan pada Sistem Sawah. Respon Agronomi Varietas Padi Terhadap Periode Kekeringan Pada Sistem Sawah, 40(3), 167-173. https://doi.org/10.24831/jai.v40i3.679 6

Wening, R. H., \& Susanto, U. (2014). Skrining Plasma Nutfah Padi Terhadap Screening of Germplasm Rice To Drought Stress. Widyariset, 17(2), 193-204.

http://dx.doi.org/10.14203/widyariset .17.2.2014.193-203

Widyastuti, Y., Purwoko, B. S., \& Yunus, D. M. (2016). Identifikasi Toleransi Kekeringan Tetua Padi Hibrida pada Fase Perkecambahan Menggunakan Polietilen Glikol (PEG) 6000. Jurnal Agronomi Indonesia (Indonesian Journal of Agronomy), 44(3), 235. https://doi.org/10.24831/jai.v44i3.137 84 